\title{
Editorial
}

\section{Intergenerational equity}

The political economy of aging made its first mark in 1981 when Peter Townsend published his seminal paper 'The structured dependency of the elderly: creation of social policy in the twentieth century'. In it he drew attention, not simply to the socially and economically submerged position of elderly people as a group, but to the way society contrived to make and keep it so. In his own words: 'I wish to put forward the thesis that the dependency of the elderly in the twentieth century is being manufactured socially and that its severity is unnecessary'. ${ }^{1}$ Almost a decade later, the vigorous debate which Townsend provoked took another decisive turn, but one which asserted that the old are taking too large a part of the national incomes of developed societies.

Gerontologists in general, led initially by Alan Walker, ${ }^{2}$ welcomed the political statement Townsend had made and a number went on to offer their own elaborations of it. In Britain, Chris Phillipson's research on UK pension policies over the past hundred years led to the publication of his influential book Capitalism and the construction of old age. ${ }^{3}$ In the United States, Carroll Estes wrote convincingly and trenchantly about the oppression of older people in America ${ }^{4}$ and their labelling as a social problem in a way which reinforced their estrangement from the market economy which purported to provide munificently for its workers. Inevitably others joined the discourse. John Myles ${ }^{5}$ among others in the US. In Europe, Martin Kohli's ${ }^{6}$ studies of enforced retirement in the German tobacco industry and Xavier Gaullier's of the same phenomena in France, $^{7}$ led an emerging consensus that employers, trade unions and governments were co-conspirators against older citizens.

Early critics of Townsend's thesis were hardly visible. The new orthodoxy gained a self-evident status. It took another new perspective on aging which emerged fully in mid-eighties - the history of aging and old age - to supply evidence which weakened some of the empirical support for 'structured dependency'. From France there already existed the influential, if flawed, earlier work of Peter Stearns, ${ }^{8}$ which by showing the great variety of experience of older people in France both supported and challenged the Townsend view. In North America, Andrew Achenbaum's ${ }^{9}$ concern with historical analysis of what constituted a 'young' society, cast further doubt on claims that the retired population in the past was ill-treated and deprived.

The concerted work of the Cambridge Group for the History and Structure of Population under the inspired leadership of Peter Laslett brought the weight of scholarship to the history of aging. Laslett's work has made its own global impact. But it was probably the work of his more junior colleague, the New Zealander David Thomson, who created the greatest controversy. In a paper on the decline of the welfare state he both undermined the myth of the Victorian golden age in Britain, ${ }^{10}$ and raised serious questions about the comparative economic treatment given to different generations and age groups.

Questions about the relative share of the national economic cake given to old people and 
to the young started to come to the fore in the US during Ronald Reagan's presidency. They arose from the reaction of commentators on the political right to the growing 'burden' of health and social security payments to the expanding retired population. On the one hand they saw the public cost of maintaining elderly people escalating at the same time as an observed growth in the discretionary income of people over 55 amounting to one-third of the national total. A view emerged in what Meredith Minkler ${ }^{11}$ calls corporate America that the old constituted a group of developing wealth whilst children and young people were suffering as a consequence of social programmes for their elders.

In 1985 a new organization formed in America under the leadership of Senator David Durenberger and Representative James Jones. They called it Americans for Generational Equity (AGE). It defines itself as a nonpartisan coalition whose mission is to build an intellectual and mass membership movement to promote the interests of the younger and future generations in the national political process. Its main targets are to increase the political power of younger people and to reduce government expenditure on social security and medicare - a form of free health care to poor people.

AGE claims that as the elderly population grows bigger it becomes richer. It is also more demanding of costly public services with the result that it is taking 'more than its fair share'. Children and young people are losing out. They point out that although constituting only $11.5 \%$ of the population the over 65 s consume $28 \%$ of the national budget and $51 \%$ of all government expenditure on social services. However, the objectives are not simply fiscal. Senator Durenberger is reported as saying: 'The assumption that each working generation will take care of the one that preceded it is finished." 11

Perhaps prompted by a public relations visit to Britain by $A G E$ representatives, David Lovibond penned a swash-buckling piece in The Daily Telegraph entitled, 'Why should we pamper these whingeing pensioners?' He wrote with gusto:

Contrary to the popular understanding and arguably as a result of filial guilt, perhaps too much sympathy is offered to the old rather than too little. After all, is the prospect of an expensively maintained, ever multiplying hoary headed horde any less dispiriting than the present hegemony of the yobs and the yahoos. ${ }^{12}$

This kind of verbal face-pulling may not match the public relations cleverness of AGE, but it espouses the same purposes - to undermine social support for the old to relieve the young. Moreover, it seeks to challenge the social contract between the generations, that a life of hard labour which includes supporting the young is repaid with income and care in retirement. Instead it is everyone for themselves from birth to death.

Those of us who contribute to the literature of gerontology are well aware that across Europe one in three of the retired population are officially below the poverty line. On the other hand, we recognize that there is a growing subgroup of retired people who continue to be prosperous into old age. This latter group are not only those with accumulated wealth but also those with inflation proof pensions and lump sum retirement bonuses. The elderly population is far from homogeneous. ${ }^{13}$

So, however distasteful their motives and publicity seeking their pronouncements, it is not possible to dismiss $\mathrm{AGE}$ and its imitators as having no case. As David Thomson's ${ }^{14}$ research on historical patterns of welfare spending in New Zealand points out, there are accumulated benefits to the elderly which leave younger age groups gravely disadvantaged. The most obvious examples are the relative difficulty for younger people to enter the housing market as expenditure on public housing has been withdrawn. Similarly, the greatest burden of unemployment has fallen on the under $25 \mathrm{~s}$; whilst health care costs for the old have escalated. State pension levels have, in real terms, fallen in recent years, but the total cost continues to rise steeply.

Paul Johnson ${ }^{15}$ observing the measurable disparities in generational shares in the US has conducted an analysis of public expenditure in the UK. His conclusions are that the British welfare state has been remarkably neutral in its allocation of resources between the generations. $\mathrm{He}$ goes on to show that any discussion of intergenerational conflict for welfare resources in the UK would establish a false division. In his view the inequalities lie along class lines in all age groups.

The publication of a collection of papers by 
an international selection of authors under the provocative title Workers versus pensioners: intergenerational justice in an ageing world ${ }^{16}$ attracted attention well beyond academic gerontology. The overt espousal of an intergenerational struggle for primacy and resources attracted the mass media and Paul Johnson, the principal editor, presented the statistical evidence as he saw it. Not all were persuaded. In a spirited review of the book Eric Midwinter ${ }^{17}$ wrote of it as a lynching party, relishing the prospect of mistrust and lack of co-operation between the generations. He goes on to challenge the authors' interpretation of state welfare transfers, their misunderstanding of the reality of the so-called dependency ratios and the ability of developed societies to sustain those no longer in paid employment.

Wherever we may stand on this polarized subject, there can be no doubt that it will challenge what had become a cosy gerontological consensus. Just as researchers in mental handicap side with the people they now label learning disabled and poverty researchers with the poor, gerontologists tend to be 'for the elders'. If we are to continue to be taken seriously by the policy makers and politicians who determine provision for older people, it will be essential for us to be able to engage both conceptually and evidentially with those who may see it as in their interest to undermine the claims of older people to their due share of satisfaction and citizenship.

Malcolm Johnson, Professor of Health and Social Welfare, The Open University, Milton Keynes MK7 6AA, UK.

\section{References}

1 Townsend P. The structured dependency of the elderly: a creation of social policy in the twentieth century. Ageing and Society 1981; 1: 5-28.

2 Walker A. The social creation of poverty and dependency in old age. Journal of Social Policy 1980;9: 49-75.

3 Phillipson C. Capitalism and the construction of old age. London: Macmillan, 1982.

4 Estes C. Political economy, health and aging. New York: Little, Brown \& Co, 1984.

5 Myles J. Income inequality and status maintenance. Res Aging 1981; 2: 123-41.

6 Kohli M, Rosenow J, Wolf J. The social construction of ageing through work: economic structure and life world. Ageing and Society 1983; 3: 23-42.

7 Gaullier X. Economic crisis and old age: old age policies in France. Ageing and Society 1982; 2: 165-82.

8 Stearns P. Old age in European society. London: Croom Helm, 1977.

9 Achenbaum A. Aging of the first new nation. In: Pifer A, Bronte L. Our aging society. New York: WW Norton \& Co, 1986.

10 Thomson $D$. The decline of social welfare: falling support for the elderly since early Victorian times. Ageing and Society 1984; 4: 451-82.

11 Minkler $\mathrm{M}$. The politics of generational equity. Social Policy. Winter, 1987.

12 Lovibond $D$. Why should we pamper these whingeing pensioners? The Daily Telegraph 1989 Jan.

13 Midwinter $E$. The wage of retirement: the case for a new pensions policy. London: Centre for Policy on Ageing, 1985.

14 Thomson D. The Welfare State and generational conflict: winners and losers. Paper presented at the Conference on Work, Retirement and Intergenerational Equity, St John's College, Cambridge, July 1988.

15 Johnson P, Falkingham J. Intergenerational transfers and public expenditure on the elderly. Ageing and Society 1988; 8: 129-46.

16 Johnson P, Conrad C, Thomson D eds. Workers v. pensioners: intergenerational justice in an ageing world. Manchester: Manchester University Press, 1989.

17 Midwinter E. Book review of Johnson P, Conrad C, Thomson D eds, Workers $v$. pensioners: intergenerational justice in an ageing world. Ageing and Society $1989 ; 9$ : 446-48. 